\title{
PENERAPAN ASKEP PADA PASIEN TN. B DENGAN TUBERKULOSIS PARU DALAM PEMENUHAN KEBUTUHAN KEAMANAN DAN KESELAMATAN
}

\author{
Nursing Care Application In Patients Mr. B With Tuberculosis Of Paru In Security Requirements \\ And Safety Security \\ Sitti Maryam, Bachtiar \\ Akper Muhammadiyah Makassar \\ Korespondensi : 08135560 6788/sittimaryam.bachtiar@yahoo.com
}

\begin{abstract}
Background. According to WHO, Tuberculosis (TB) is a global health problem, half a percent of the world's population is affected by the disease, mostly in developing countries, in Indonesia in 2013 of 183 per 100,000 people with mortality of 25 per 100,000 population, 399 per 100,000 population with a mortality rate that also increased to 41 per 100,000 population. The data shows that the incidence of TB in Indonesia is still high, so the prevention and eradication of TB_Paru is done by Directly Observe treatment approach of Shortcourse (DOTS) or TB_Paru treatment with direct supervision by the Swallowing Supervisor (PMO) so that in this case study is expected can help patients with pulmonary TB in the fulfillment of their needs so that the number of TB suffering decreases.

Aim. Gain a picture of the success of the application of askep on Mr. B with Pulmonary Tuberculosis in meeting security and safety needs.

Method. This case study uses descriptive analysis design. With a nursing process approach. of pulmonary tuberculosis patients in meeting security and safety needs. The data collected in this study used the format of assessment, interview format and observation sheet.

Results. Nursing Diagnosis, Risk of spread of infection b / d lack of knowledge to avoid exposure to pathogens. The result shows the behavior of prevention of disease transmission that is patient already use mask, client seems to start to shut mouth when cough, client does not seem to throw sputum at any place, window of the house appear already open at the time of day. Clients say, starting to understand that the disease Pulmonary TB is one of the infectious diseases, clients say already understand how the transmission process and how to prevent the disease in his pain. Objective: TTV obtained results: TD: 130/90 mmHg, pulse: 86 x/min, Temperature: $38^{\circ} \mathrm{C}$, Respiration: $28 \mathrm{x} / \mathrm{min}$.

Conclusion. Risk of spreading infection $b / d$ Lack of knowledge to avoid exposure to pathogens is resolved supported by data that matches the established outcome criteria.
\end{abstract}

Keywords: Nursing care, safety and safety, Pulmonary Tuberculosis

\begin{abstract}
Abstrak
Latar belakang. Menurut WHO, Tuberculosis (TB) menjadi masalah kesehatan dunia, setengah persen dari penduduk dunia terserang penyakit ini, sebagian besar berada di Negara berkembang, di Indonesia tahun 2013 sebesar 183 per 100.000 penduduk dengan angka kematian sebesar 25 per
\end{abstract}


100.000 penduduk, tahun 2014 meningkat menjadi 399 per 100.000 penduduk dengan angka kematian yang juga miningkat menjadi 41 per 100.000 penduduk. Data tersebut menunjukkan, angka kejadian TB di Indonesia masih tinggi, sehingga diperlukan upaya pencegahan dan pemberantasan TB_Paru yang di lakukan dengan pendekatan Directly Observe treatment Shortcourse (DOTS) atau pengobatan TB_Paru dengan pengawasan langsung oleh Pengawas Menelan Obat (PMO) sehingga dalam studi kasus ini diharapkan dapat membantu penderita TB paru dalam pemenuhan kebutuhannya sehingga angka penderitaan TB menurun.

Tujuan. Memperoleh gambaran keberhasilan penerapan askep pada Tn B dengan Tuberculosis Paru dalam pemenuhan kebutuhan keamanan dan keselamatan.

Metode. Studi kasus ini menggunakan rancangan analisis deskriptif. Dengan pendekatan proses keperawatan. terhadap pasien tuberculosis paru dalam pemenuhan kebutuhan keamanan dan keselamatan. Data yang dikumpulkan dalam penelitian ini menggunakan format pengkajian, format wawancara dan lembar observasi.

Hasil. Diagnosa keperawatan, Resiko penyebaran infeksi b/d kurangnya pengetahuan untuk menghindari pemaparan pathogen. Hasilnya menunjukkan prilaku pencegahan penularan penyakit yaitu pasien sudah menggunakan masker, klien nampak mulai menutup mulut saat batuk, klien nampak tidak membuang dahak di sembarang tempat, jendela rumah nampak sudah terbuka pada saat siang hari. Klien mengatakan, mulai memahami bahwa penyakit TB Paru adalah salah satu penyakit yang menular, klien mengatakan sudah memahami bagaimana proses penularan dan cara pencegahan penyakit yang di deritanya. Obyektif: TTV didapatkan hasil : TD : 130/90 $\mathrm{mmHg}$, Nadi : 86 x/menit, Suhu : $38^{\circ} \mathrm{C}$, Pernapasan : 28 x/menit.

Kesimpulan. Resiko penyebaran infeksi b/d Kurangnya pengetahuan untuk menghindari pemaparan pathogen teratasi didukung dengan data yang sesuai dengan kriteria hasil yang ditegakkan.

Kata kunci : Asuhan Keperawatan, keamanan dan keselamatan, Tuberculosis Paru

\section{PENDAHULUAN}

Penyakit tuberculosis (TB) masih menjadi masalah kesehatan dunia dimana WHO melaporkan bahwa setengah persen dari penduduk dunia terserang penyakit ini, sebagian besar berada di Negara berkembang di antara tahun 2009-2011 hampir $89 \%$ penduduk dunia menderita TB. Menurut Laporan WHO tahun 2011 penderita TB di dunia sekitar 12 juta atau 178 per 100.000 dan setiap tahunnya ditemukan 8,5 juta dengan kematian sekitar
1,1 juta. Kondisi ini lebih baik di bandingkan dengan tahun 2009 secara global di lakukan sekitar 39\% Penyakit ini menyerang di Asia terutama di 22 Negara beban tinggi TB setiap tahunnya di temukan kasus TB baru sekitar 9,4 juta dan kematian sebesar 3,8 juta. Dimana di perkirakan semua kasus TB yang ada di dunia sebanyak 14 Juta lebih, pada umumnya menyerang kelompok usia produktif. (Nizar, 2017). Data WHO pada tahun 2014 menunjukkan TB membunuh 
1,5 juta orang di dunia, kematian terjadi pada 890.000 laki-laki, 480.000 pada perempuan dan 180.000 pada anak-anak. Terdapat enam Negara yang memiliki jumlah kasus baru TB terbesar di dunia yakni India sebesar 2.200.000 kasus, Indonesia sebesar 1.000.000 kasus, Cina sebesar 930.000 kasus, Nigeria sebesar 570.000 kasus, Pakistan sebesar 500.000 kasus, dan Afrika Selatan sebesar 450.000 kasus. Di Indonesia pada tahun 2013 angka insiden TB sebesar 183 per 100.000 penduduk dengan angka kematian TB sebesar 25 per 100.000 penduduk. Pada tahun 2014 angka insiden meningkat menjadi 399 per 100.000 penduduk dengan angka kematian yang juga miningkat menjadi 41 per 100.000 penduduk. Dari data tersebut menunjukkan bahwa angka kejadian TB di Indonesia masih tinggi, sehingga diperlukan upaya promotif dan kuratif untuk mencegah penularan penyakit TB. (Tiara, Laode, \& Karma, 2015). Data dari dinas Kesehatan Provinsi Sulawesi Selatan pada tahun 2011, penderita Penyakit menular ini mencapai 8.939 kasus dengan peningkatan jumlah penderita sebesar 55\%. Angka ini meningkat signifikan di banding tahun sebelumnya yang hanya 7.783 kasus. Kabupaten Takalar menduduki peringkat pertama dalam jumlah kasus dengan pertumbuhan penderita TB paru di atas $109 \%$, menyusul pare-pare $79 \%$, Pinrang 75\%, disusul Makassar 70\%, Kabupaten Luwu 33\%, Jeneponto 36\%. (Syam, Riskiyani, \& Rachman, 2013)

Tuberculosis ditularkan dari orang ke orang oleh transmisi melalui udara. Individu terinfeksi, melalui berbicara, batuk, bersin, tertawa atau bernyanyi, melepaskan droplet. Droplet yang besar menetap, sementara droplet yang kecil bertahan di udara dan terhirup oleh individu yang rentan. (Jourdan, C et al., 2016)

Upaya pencegahan dan pemberantasan TB_Paru di lakukan dengan pendekatan Directly Observe treatment Shortcourse (DOTS) atau pengobatan TB_Paru dengan pengawasan langsung oleh Pengawas Menelan Obat (PMO). (Kawatstu, Let al., 2018)

Dalam penanganan program, semua penderita TB Paru yang di temukan di tindaklanjuti dengan paket-paket pengobatan intensif. Melalui paket pengobatan yang di minum secara teratur dan lengkap, diharapkan penderita akan dapat disembuhkan dari Penyakit TB yang di deritanya. Namun demikian dalam proses selanjutnya tidak tertutup kemungkinan terjadinya kegagalan 
pengobatan akibat dari paket pengobatan yang tidak terselesaikan atau drop out (DO), terjadinya resistensi obat atau kegagalan dalam penegakan diagnosa diakhir pengobatan. Adapun angka tingkat kesembuhan dari penderita TB BTA+ tahun 2008 tercatat sebesar $92,8 \%$, menurun pada tahun 2009 menjadi $51,10 \%$ tetapi mengalami peningkatan lagi pada tahun 2010 sebesar 89\%. (Sudarianto, Mursalim, \& Nur, 2011)

Dalam studi kasus ini diharapkan dapat bermanfaat untuk membantu penderita TB paru dalam pemenuhan kebutuhan aman dan selamat sehingga angka penderitaan TB menurun karena di lihat dari beberapa hasil penelitian bahwa angka kejadian $\mathrm{Tb}$ semakin meningkat dari tahun ke tahun.

Terdapat kesenjangan yang besar dalam deteksi kasus TB maupun resistensi multi obat TB antara orang dewasa dengan anak-anak, khususnya dalam hal diagnosa serta pengobatan. WHO megungkapkan bahwa ada sekitar 450.000 orang yang mengalami TB pada tahun 2012 dan sekitar 170.000 orang yang masuk dalam daftar TB tersebut telah meninggal dunia. (Sullis, G., et al., 2018)

Dari kasus diatas penulis tertarik untuk menyusun proposal dengan judul
Penerapaan Asuhan Keperawatan pada klien gangguan system pernafasan: TB Paru dalam Pemenuhan Kebutuhan Aman dan selamat secara konperhensif tahun 2017 di lihat dari hasil penelitan menunjukkan bahwa prevalensi TB dari tahun ke tahun semakin meningkat.

\section{METODE}

Penelitian ini dilakukan di Puskesmas Dahlia pada tanggal 9 s/d 15 April 2018, dengan desain penelitian yang digunakan adalah analisis deskriptif dengan pendekatan studi kasus, yaitu penelitian yang berfokus pada suatu kasus tertentu untuk diamati dan dianalisis secara cermat sampai tuntas.

Populasi dalam study kasus ini adalah semua pasien dengan masalah Tuberkulosis Paru. Sampel dalam study kasus ini sesuai dengan kriteris inklusi yaitu pasien TB Paru yang mengalami gangguan kebutuhan keamanan dan keselamatan yang sedang dirawat di ruang perawatan.

Alat pengumpulan data dalam study kasus ini menggunakan format pengkajian, format wawancara dan lembar observasi.

Analisa data yang dilakukan pada study kasus ini adalah dengan mendeskripsikan informasi yang telah 
tersusun dan melakukan penarikan kesimpulan serta pengambilan tindakan. Data yang telah tersusun kemudian disajikan dalam bentuk narasi yang mudah dipahami

\section{HASIL PENELITIAN}

Berdasarkan hasil pengkajian pada klien didapatkan masalah dengan diagnosa Resiko penyebaran infeksi berhubungan dengan Kurangnya pengetahuan untuk menghindari pemaparan pathogen. Perencanaan sesuai masalah keperawatan pada klien, maka penulis melakukan tindakan keperawatan selama 1x24 jam, tidak terjadi penularan (selama menderita TB).

Setelah dilakukan tindakan keperawatan, hasil evaluasi dari tindakan yang dilakukan dengan metode SOAP, dengan data subyektif : klien mengatakan mulai memahami bahwa Penyakit TB Paru adalah salah satu penyakit menular, klien mengatakan sudah memahami bagaimana proses penularan dan cara pencegahan Penyakit yang di deritanya. Obyektif: tanda-tanda vital (TTV) didapatkan hasil : Tekanan darah : 130/90 mmHg, Nadi : 86 $\mathrm{x} /$ menit, Suhu : $38^{\circ} \mathrm{C}$, Pernapasan : 28 $\mathrm{x} /$ menit. klien Nampak mulai menggunakan masker tapi masih sering di lepaskan dengan alasan belum terbiasa menggunakan masker, klien Nampak mulai menutup mulut saat batuk, klien Nampak membuang dahak di sembarang tempat, jendela rumah Nampak sudah terbuka pada saat siang hari. Analisis : masalah belum teratasi. Planning : lanjutkan intervensi yaitu Identifikasi faktor resiko dan paparan terhadap orang lain, Identifikasi cara penularan, Penempatan di kamar isolasi, Laksanakan tindakan kewaspadaan pencegahan infeksi, Jelaskan pada klien mengenai penularan dan tanggung jawab klien di rumah sakit/di rumah, Amankan lingkungan dan peralatan yang digunakan dengan dekotaminasi dan sterilisasai, Kolaborasi dengan dokter untuk penanganan medis dan pemeriksaan.

\section{PEMBAHASAN}

Pembahasan tentang "Penerapan Asuhan Keperawatan pada Klien Tn"B" dengan Tuberculosis Paru Dalam Pemenuhan Kebutuhan Keamanan Dan keselamatan" telah dilaksanakan pada selasa tanggal 09 s/d 15 April 2018. Di samping itu, akan dikemukakan pula faktor terkait kurangnya pengetahuan maupun hambatan dalam memberikan Asuhan Keperawatan pada Tn.B yang akan 
diuraikan sesuai dengan tahap proses keperawatan.

Hasil pengkajian pada Tn "B" didapatkan data bahwa riwayat keluhan utama yang dirasakan klien mengeluh batuk berdahak bercampur darah di sertai dengan nyeri dada, nyeri yang dirasakan seperti tertusuk-tusuk, nyeri pada daerah dada, skala nyeri 3 (ringan), klien mengatakan nyeri yang dirasakan sewaktuwaktu dengan durasi yang tidak menentu. Klien nampak meringis sambil mengelus bagian dada. Hasil pengkajian nyeri pada Tn."B" diatas sejalan dengan teori uliyah \& hidayat (2012) bahwa pengkajian terhadap masalah keamanan dan keselamatan di antaranya pengkajian terhadap factor-faktor yang mempengaruhi atau menyebabkan infeksi akibat daya tahan tubuh menurun, usia, dan lain-lain, seperti panas, nyeri pada daerah lokasi infeksi.

Pada kebutuhan aktivitas, klien mengatakan sebelum terdiagnosa TB Paru kegiatan sehari-harinya dapat di lakukan dengan baik tanpa ada hambatan dan keluhan, tidak ada penggunaan alat bantu. Setelah terdiagnosa TB Paru kegiatan sehari-hari klien terganggu karena harus membatasi aktivitas sebab ketika beraktivitas lebih klien mudah merasa sesak nafas, nyeri dada dan batuk teori tersebut sejalan dengan teori padila (2013).

Pada Diagnosa Keperawatan, Menurut Soemantri (2008), diagnose yang mungkin muncul pada klien tuberculosis dalam pemenuhan kebutuhan keamanan dan keselamatan yaitu Resiko penyebaran infeksi berhubungan dengan kurangnya pengetahuan untuk menghindari pemaparan pathogen hal itu sejalan dan berfokus dengan data yang di dapatkan saat di lakukan pengkajian pada tanggal 09 April 2018 yaitu data subyektif klien mengatakan Penyakit yang di derita bukan Penyakit menular melainkan Penyakit turunan keluarga, klien mengatakan tidak mengetahui proses penularan dan cara pencegahan Penyakit yang di deritanya (TB Paru). Data obyektif didapatkan Hasil dari pemeriksaan tanda-tanda vital (TTV) klien didapatkan hasil : Tekanan darah : 130/90 mmHg, Nadi : 86 x/menit, Suhu : $38^{\circ} \mathrm{C}$, Pernapasan : $28 \mathrm{x} / \mathrm{menit}$, pemeriksaan pada mata klien, konjungtiva anemis, klien Nampak meringis saat batuk sambil mengelus-ngelus dada, klien Nampak tidak menggunakan masker, klien Nampak batuk tanpa menutup mulut, klien Nampak membuang dahak di sembarang tempat, keadaan rumah Nampak pengap. 
Pada perencanaan, Peneliti akan membahas rencana keperawatan sesuai dengan prioritas masalah pada pasien. Rencana Keperawatan dengan tujuan setelah di lakukan tindakan keperawatan selama 7 hari diharapkan tidak terjadi penularan (selama menderita TB).dengan kriteria hasil : Klien menunjukkan perilaku pencegahan penularan.

Intervensi yang direncanakan peneliti untuk mengatasi kurang pengetahun klien dalam menghindari pemaparan pathogen yaitu : Identifikasi faktor resiko dan paparan terhadap orang lain, Identifikasi cara penularan, Penempatan di kamar isolasi, Laksanakan tindakan kewaspadaan pencegahan infeksi, Jelaskan pada klien mengenai penularan dan tanggung jawab klien di rumah sakit/di rumah, Amankan lingkungan dan peralatan yang digunakan dengan dekotaminasi dan sterilisasai, Kolaborasi dengan dokter untuk penanganan medis dan pemeriksaan.

Pada tahap ini tidak terdapat adanya kesenjangan antara teori dan hasil study kasus karena intervensi yang terdapat dalam teori sama dengan intervensi yang disusun pada hasil study kasus. sesuai dengan teori intervensi yang dituliskan menurut Soemantri (2008). dan kriteria hasil berdasarkan NIC (Nursing
Intervension Classification) dan NOC (Nursing Outcome Classification).

Hasil implementasil yang di lakukan pada hari pertama tidak sejalan dengan teori Soemantri (2008) mengenai tujuan dan kriteria hasil karena masalah yang muncul dapat teratasi, dimana klien belum menunjukkan perilaku pencegahan penularan Penyakit TB Paru.

Evaluasi adalah tahap akhir dari proses keperawatan yang di gunakan sebagai titik acuan terhadap tindakan yang telah di lakukan, apakah masalah tersebut teratasi atau tidak teratasi. Pada diagnosa Resiko penyebaran infeksi berhubungan dengan Kurangnya pengetahuan untuk menghindari pemaparan pathogen, hasil evaluasi yang dilakukan pada hari sabtu tanggal 15 April 2018 dengan masalah keperawatan Resiko penyebaran infeksi berhubungan dengan Kurangnya pengetahuan untuk menghindari pemaparan pathogen dapat teratasi, didukung dengan data klien yang mengatakan, mulai memahami bahwa Penyakit TB Paru adalah sala satu yang menular, klien mengatakan sudah memahami bagaimana proses penularan dan cara pencegahan Penyakit yang di deritanya. Obyektif: tanda-tanda vital (TTV) didapatkan hasil : Tekanan darah : 
130/90 mmHg, Nadi : 86 x/menit, Suhu : $38^{\circ} \mathrm{C}$, Pernapasan : $28 \mathrm{x} /$ menit. klien Nampak mulai menggunakan masker tapi masih sering di lepaskan dengan alasan belum terbiasa menggunakan masker, klien Nampak mulai menutup mulut saat batuk, klien Nampak membuang dahak di sembarang tempat, jendela rumah Nampak sudah terbuka pada saat siang hari. Data diatas belum sesuai dengan kriteria hasil yang tegakkan.

\section{KESIMPULAN}

Dalam melakukan pengkajian keperawatan pada Tn. B, peneliti menggunakan beberapa metode yaitu wawancara, observasi, pemeriksaan fisik dan studi dokumentasi yang diperoleh dari pasien, catatan medis, hasil pemeriksaan diagnostic petugas kesehatan. Diagnose keperawatan yang muncul pada Tn. B adalah Berdasarkan hasil pengkajian, diagnose keperawatan yang muncul pada Tn"B" adalah resiko penyebaran infeksi berhubungan dengan kurangnya pengetahuan untuk menghindari pemaparan pathogen.

Rencana keperawatan di harapkan dalam waktu 1x24 Tidak terjadi penularan (selama menderita TB) dengan kriteria hasil : Klien menunjukkan perilaku pencegahan penularan. Rencana keperawatan yang dilakukan yaitu: Identifikasi faktor resiko dan paparan terhadap orang lain, Identifikasi cara penularan, Penempatan di kamar isolasi, Laksanakan tindakan kewaspadaan pencegahan infeksi, Jelaskan pada klien mengenai penularan dan tanggung jawab klien di rumah sakit/di rumah, Amankan lingkungan dan peralatan yang digunakan dengan dekotaminasi dan sterilisasai, Kolaborasi dengan dokter untuk penanganan medis dan pemeriksaan.

Implementasi keperawatan yang di lakukan yaitu mengidentifikasi faktor resiko dan paparan terhadap orang lain, mengidentifikasi cara penularan, menempatan di kamar isolasi, melaksanakan tindakan kewaspadaan pencegahan infeksi, menjelaskan pada klien mengenai penularan dan tanggung jawab klien di rumah sakit/di rumah, mengamankan lingkungan dan peralatan yang digunakan dengan dekotaminasi dan sterilisasai, mengkolaborasi dengan dokter untuk penanganan medis dan pemeriksaan.

Hasil evaluasi pada masalah Resiko penyebaran infeksi berhubungan dengan Kurangnya pengetahuan untuk menghindari pemaparan pathogen teratasi sebagian di dukung dengan data subjektif klien yang mengatakan penyakit yang di 
derita bukan Penyakit menular melainkan penyakit turunan keluarga, klien mengatakan tidak mengetahui proses penularan dan cara pencegahan Penyakit yang di deritanya (TB Paru). Data obyektif : tanda-tanda vital (TTV) didapatkan hasil : Tekanan darah : 130/90 mmHg, Nadi : 86 $\mathrm{x} / \mathrm{menit}$, Suhu : $38^{\circ} \mathrm{C}$, Pernapasan : 28 $\mathrm{x} /$ menit. Pemeriksaan pada mata klien, konjungtiva anemis, klien Nampak meringis saat batuk, klien Nampak tidak menggunakan masker, klien Nampak batuk tanpa menutup mulut, klien Nampak membuang dahak di sembarang tempat, keadaan rumah Nampak pengap.

\section{SARAN}

Dapat meningkatkan pengetahuan dan kemandirian masyarakat tentang penerapaan asuhan keperawatan pada klien tuberculosis paru dalam pemenuhan kebutuhan keamanan dan keselamatan.

Dapat mengembangkan wawasan pengetahuan, menambah keluasan ilmu dan terapan teglonogi keperawatan dalam hal prinsip-prinsip penerapan asuhan keperawatan pada klien tuberculosis paru dalam pemenuhan kebutuhan keamanan dan keselamatan.

Dapat menjadi bahan referensi serta acuan untuk di kembangkan dalam memberikan asuhan keperawatan pada klien tuberculosis paru dalam pemenuhan kebutuhan keamanan dan keselamatan serta meningkatkan pengalaman dalam mengimplementasikan tindakan keperawatan.

\section{UCAPAN TERIMA KASIH}

Bapak Prof. Dr. H. Ambo Asse, M.Ag, selaku ketua BPH Akademi Kesehatan Muhammadiyah Makassar, Ibunda Ratna Mahmud S.Kep., Ns., M.Kes, selaku Direktur Akademi Keperawatan Muhammadiyah Makassar, Kepala Puskesmas Dahlia Makassar beserta seluruh Staff dan semua pihak yang telah memberikan support dan bantuannya yang tidak dapat disebutkan satu persatu.

\section{DAFTAR PUSTAKA}

Dharma, K. K. (2011). metodologi Penelitian Keperawatan. Jakarta: Trans Info Media.

Doenges, M. E., Moorhouse, M. F., \& Geissler, A. C. (2014). Rencana Asuhan Keperawatan Pedoman Untuk Perencanaan Dan Pendokumentasian Perawatan Pasien. Jakarta: EGC. 
Hidayat, A. A., \& Uliyah, M. (2012). Buku Ajar Kebutuhan Dasar Manusia. Surabaya: Health Books Publishing.

Hidayat, A. A., \& Uliyah, M. (2014). Pengantar Kebutuhan Dasar Manusia. Jogjakarta: Salemba Medika.

Jourdan, C., Lisa, T., Douglas, P., Desai, A.S. (2016). Contact Investigations Around Mycobacterium tuberculosis Patients Without Positive Respiratory Culture https://www.nursingcenter.com/journalarticle?Article_ID $=3411966 \&$ Journal_ID $=4209$ 59\&Issue ID=3411494. Lippicot, NursingCenter.

Kawatstu, L., Uchimura, K., Ohkado, A., Kato, S. (2018), A combination of quantitative and qualitative methods in investigating risk factors for lost to follow-up for tuberculosis treatment in Japan - Are physicians and nurses at a particular risk. https://www.ncbi.nlm.nih.gov/pubmed/29906287. doi: 10.1371/journal.pone.0198075. eCollection 2018.NCBI, Pubmed.

Manurung, S., Suratun, Krisanty, P., \& Ekarini, N. P. (2013). Gangguan Sistem Pernafasan Akibat Infeksi. DKI Jakarta: CV. Trans Info Medika.

Nizar, M. (2017). Pemberantasan Dan Penanggulangan Tuberculosis. Yogyakarta: Gosyen Publishing.

Nugroho, T. (2011). Asuhan Keperawatan Maternitas, Anak, Bedah, Penyakit Dalam. Yogyakarta: Nuha Medika.

Nurarif, A. H., \& Kusuma, H. (2015). Aplikasi Asuhan Keperawatan Berdasarkan Diagnosa Medis Dan Nanda NIC-NOC Jilid 3. Jogjakarta: Mediaction.

Padila. (2013). Asuhan Keperawatan Penyakit Dalam. Yogyakarta: Nuha Medika.

Sudarianto, Mursalim, \& Nur, M. (2011). Profil Kesehatan Sulawesi Selatan 2011. 71.

Sullis, G., Combary, A., Getahun, H., Gnanou, S., Giorgetti, P.F., Konseimbo, A., Capone, S., Hamada, Y., Baddeley, A., Matteelli, A. (2018). Implementation of tuberculosis prevention for exposed children, Burkina Faso. https://www.ncbi.nlm.nih.gov/pubmed/29904221. doi: 10.2471/BLT.17.201343. Epub 2018 Apr 20. NCBI, Pubmed.

Syam, M. S., Riskiyani, S., \& Rachman, W. A. (2013). Dukungan Sosial Penderita Tuberculosis Paru Di Wilayah Kerja Puskesmas Ajangale Kabupaten Bone 2013. 2.

Tiara, H., Laode, A. A., \& Karma, I. (2015). Analisis Spasial, Kolerasi Dan Trend Kasus TB Paru BTA positif Menggunakan WEB Sistem Informasi Geografis Di Kota Kendari Tahun 2013-2015. 2.

Wardhani, R. (2014). Buku Ajar Dasar-Dasar Riset Keperawatan. Yogyakarta: Nuha Medika. 


\section{Lampiran :}

\section{DIAGNOSA KEPERAWATAN}

a. Resiko penyebaran infeksi berhubungan dengan Kurangnya pengetahuan untuk menghindari pemaparan pathogen

Tabel 2.1 Perencanaan Keperawatan

\begin{tabular}{|c|c|}
\hline Intervensi & Rasional \\
\hline $\begin{array}{l}\text { a) Identifikasi faktor resiko dan paparan } \\
\text { terhadap orang lain }\end{array}$ & $\begin{array}{l}\text { a) Mengetahui masalah yang timbul dan } \\
\text { penanganan masalah secara efektif. } \\
\text { b) Memudahkan intervensi selanjutnya. }\end{array}$ \\
\hline b) Identifikasi cara penularan & c) Mencegah penularan infeksi \\
\hline $\begin{array}{l}\text { c) Penempatan di kamar isolasi } \\
\text { d) Laksanakan tindakan kewaspadaan } \\
\text { pencegahan infeksi }\end{array}$ & $\begin{array}{l}\text { d) Mencegah bahayanya infeksi dan } \\
\text { menurunkan resiko. }\end{array}$ \\
\hline $\begin{array}{l}\text { e) Jelaskan pada klien mengenai } \\
\text { penularan dan tanggung jawab klien di } \\
\text { rumah sakit/di rumah. }\end{array}$ & $\begin{array}{l}\text { e) Meningkatkan pemahaman dan } \\
\text { pengetahuan klien tentang resiko } \\
\text { penularan di rumah sakit dan di } \\
\text { rumah. }\end{array}$ \\
\hline $\begin{array}{l}\text { f) Amankan lingkungan dan peralatan } \\
\text { yang digunakan dengan dekotaminasi } \\
\text { dan sterilisasai. }\end{array}$ & $\begin{array}{l}\text { f) Mencegah berkembangbiaknya } \\
\text { infeksi. }\end{array}$ \\
\hline $\begin{array}{l}\text { g) Kolaborasi dengan dokter untuk } \\
\text { penanganan medis dan pemeriksaan }\end{array}$ & $\begin{array}{l}\text { g) Mempercepat penyembuhan dan } \\
\text { mengobati TBC }\end{array}$ \\
\hline
\end{tabular}


b. Risiko tinggi infeksi (penyebaran/aktivasi ulang) berhubungan dengan pertahanan primer tak adekuat.

\section{Tabel 2.2 Perencanaan Keperawatan}

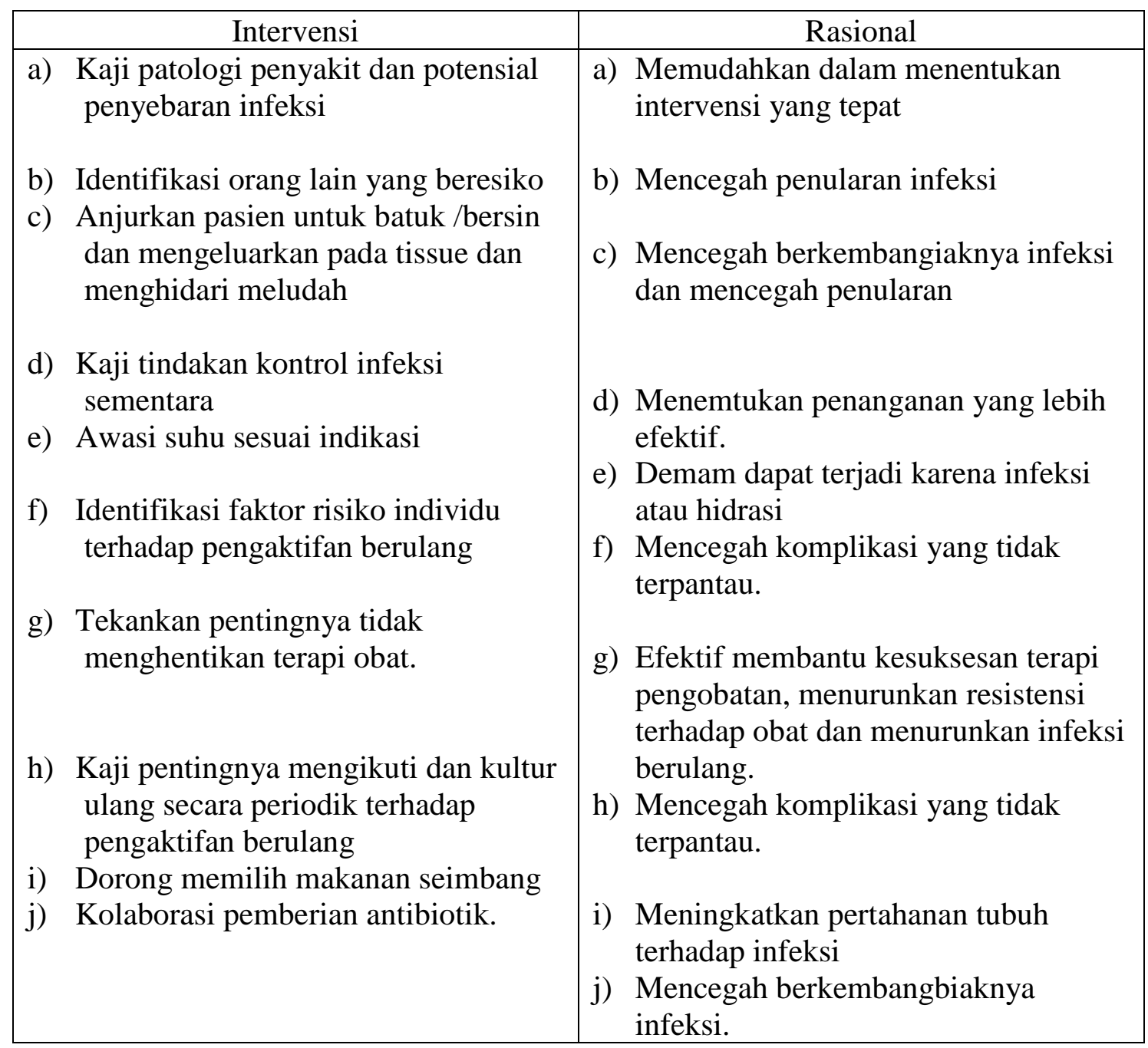


